\title{
Banyumas Potential For Local Culture-Based Tourism
}

\author{
Rawuh Edy Priyono \\ rawuhpriyono@yahoo.co.id
}

\author{
Sulyana Dadan \\ kangdadan_garut@yahoo.com
}

\begin{abstract}
Banyumas is rich in traditional art, customs, and tradition that should be preserved as the nation's asset. However, the potential seems disorganized; and thus this research was conducted to find the synergy among tourism stakeholders in developing tourism in Banyumas. The result of this research shows that the cause of the decreasing number of visitors/tourists in Banyumas is that there are not enough attractive cultural performance from the local potential. The stakeholders cooperation are very important to manage as well as develop Banyumas tourism. It will also be encouraging by the support of the local government, private sectors, and the local people. The result also recommends that there should be a forum of stakeholders that periodically consolidates their roles in Banyumas tourism. Thus, they can together develop as well improve the tourism in Banyumas.
\end{abstract}

\section{Keywords-Clocal culture, Banyumas tourism}

\section{I.INTRODUCTION}

Tourism in Banyumas and the surrounding areas has been well-known especially for the natural beauty of Baturraden. Tourists can enjoy the wonderful panoramic view, the peaceful atmosphere, and also the fresh air of Mount Slamet slope. They can also see the outstanding beauty of pine trees that grow in Lembah Serayu (Serayu Slope).

Banyumas Residency has various tourist resorts that can be categorized into natural resorts likeBaturraden, man made resorts (ie Owabong in Purbalingga), culture and historic resorts, such as KotaLama Banyumas (Banyumas Old City) and Puppet Museum, and religious resorts (Masjid Saka Tunggal and Maria Cave in Kaliori). Moreover, there are handicraft industries, painting centers, and culinary areas.

As a tourist destination, Banyumas has much culture which is rich in local tradition value and needs to be developed and preserved. The customs or art are the main part of tourism development in Banyumas. The friendly local people as well as the committed tourism stakeholders can also support the development.

However, it seems that the local authority has not really made their effort to maximize the tourism assets. For example, thetraditional art still lacks a little polish and there are dishonest pot plant sellers that consequently diminish the image of Banyumas. Besides, it is possible that tourists will not pay a visit to this cultural region.

Thus, the local government, private sector, and local people should support the development and preservation of Banyumas local culture. In fact, each party are still not able to work together and this situation may be disadvantageous.

Based on the conditions, this research tries to find the answers of the following questions: how is the development of the local culture-based tourism potential

\section{II.RESEARCH METHOD \\ A.Research Approach}

This qualitative research is focused on the purpose to find extensive knowledge of the Banyumas potential for local culture-based tourism.

\section{B.Location}

Banyumas Regency becomes the main location of the research and the researcher involved the people who actively participate in cultural activities and tourism industries.

\section{C.Informants}

In a qualitative research, a purposive technique can be used to determine informants (Rusidi, 1993); and the aim is to find particular subjects who understand research aspects; in this case understand the cultural elements in tourism. In Cresswell's view informants are intentionally chosen in order to be able to give best answers (Cresswell, 2002).

\section{D,Data Collection Technique}

Focus Group Discussion

Cultural activists and tourism stakeholders hold a group discussion to find factual information on specific topics.

In-depth Interview

The researcher, by doing a semi-structured interview, had an interview with public figures especially those who are active in cultural events and tourism.

\section{E.Data Analysis Technique}

The data is analyzed by a model of interactive analysis (Miles and Huberman, 1992). After collecting the data, the analysis goes to data reduction, data display, and conclusion drawing. The steps are classifying, categorizing, interpreting, formating information into narration or pictures, and writing it in a qualitative text (Cresswell, 2002).

\section{III.DISCUSSION}

Banyumas Regency has a number of potential tourist resorts and one of them is Baturraden that is visited by more than 400 thousands visitors per year. Their favourite spots are PancuranTujuh (Seven Sulphur Springs), Wanawisata Baturraden (Baturraden forest), Curug Cipendok(Cipendok Waterfall), CurugGede (Gede Waterfall), CurugCeheng (CehengWaterfall), and Pancuran Telu (Three Sulphur Springs).

Furthermore, the stakeholders are able to provide facilities and accommodation (hotels, inns) and so far Banyumas has 162 facilities consisting of 5 star hotels and 157 non-star hotels (Central Statistic Agency, 2009). Most of 
the hotels are in Baturraden i.e. 2 star hotels and 99 non-star hotels.

The unattractive local culture might be the cause of the decreasing number of visitors in Banyumas. Eyang Nar, a budayawan (a culture expert), states that Banyumas tourism development is classified into urban and rural sectors. The urban sector development refers to education tourism, shopping tourism, and culinary tourism; whereas the rural sector is usually more varied especially in Baturraden area and KotaLama Banyumas (Banyumas Old City).

People will find much culture in Banyumas Old City such as macapatan (Javanese classical verses), sedekahbumi (a thanksgiving ceremony for the earth), jumenengan (commemorating the enthronement of) Raden Joko Kaiman, and the local people's daily activities. Moreover, Eyang Nur gave his opinion:

Tourists are basically interested in seeing the farmers' activity which is different from their own culture. They show strong interests in rice field ploughing, wood sawing, and watching traditional culture of sedekahbumi.Let's take Bali as an example. It has become the point of interest because the people's ritual activities, like praying in temples and wood carving, are very natural and have become their way of life.?(Nar)

It is clear that the natural daily life is very compelling and tourism will be more attractive if it has distinct elements so that people will be motivated to visit the place. Sharplay (in Pitana and Gayatri, 2005) outlines that the motivation for a person to go on a trip is culture motivation, that is the desire to know other culture, tradition and custom, and cultural heritage of a place.

Banyumas Old City is rich in genuine cultural heritage either in the form of art performance or classical tradition that is still maintained by the local people. For example, larungan rite (throwing offerings to Serayu River) that symbolizes a thankful expression to God that has made the people of Banyumas live in prosperity. However, the procession has not been organized so well that it has not given positive effect upon the local people.

The other example is Dawuhan where the residents really believe that water from the sacred well in the village is miraculous. Until today, many people come from other towns or areas to take the water and use it for many purposes like therapy (medical treatment), anti-ageing, etc. This is similar to a phenomenon when thousands of people visited Ponari, in Jombang - East Java, to heal their illness by drinking the water with the help of a magic stone which was obtained after being struck by lightning.

The above phenomenon can be called 'the rational of irrationality.' Ponari's or Dawuhan's magic water becomes a symbol of people's different behaviour when they have health problems. Some people prefer to see their doctors or go to hospitals; while some others believe more in dukun (shaman).
Table 1. Matrix of Tourism Development by Sectororiented

\begin{tabular}{|l|l|}
\hline \multicolumn{1}{|c|}{ Urban Sector } & \multicolumn{1}{c|}{ Rural Sector } \\
\hline Education Tourism & Historic Tourism \\
Shopping Tourism & Culture Tourism \\
Culinary Tourism & Art Tourism \\
Performance & Nature Tourism (Baturraden) \\
\hline
\end{tabular}

Purwokerto also becomes a tourist destination especially for people from Cilacap, Purbalingga, Banjarnegara, and even Wonosobo. They visit the city for only enjoying traditional food such as soto in JalanBank (Bank Street) or gethuk (sweet fried cassava) in Sokaraja. The city is getting more dynamic with the growth of culinary centers in GOR Satria (Satria Sport Hall) and modern shopping centres.

Baturraden can be more interesting if the local authority are able to maximize the local people potential. It also needs better access, art performance, travel and accommodation, and public amenities. In years past, they were in good conditions; but now the conditions are different particularly after the new autonomy era when the local government assets was handed over to the state-owned forestry company (Perhutani) because they are Perhutani's income support. So, in developing the potential, the government needs to be aware of Baturraden's strengths and weaknesses as a tourists destination.

It is in line with Eyang Nar's statement that tourism needs characteristics, attractions, cleanliness, and promotion. Tourism practitioners (Tkd) have specific slogan called 'Rames' as the abbreviation for ramah (friendly), aman (safe), and sejahtera (prosperous).Friendliness and security are two most important aspects that usually become tourists consideration to visit this tourist area.

To sum up, the development will be more encouraging if it is supported by the local government, the private sectors, and the public. However, as mentioned before, they have not been able to work together, even there is such rivalry among the three parties. As a result, it can endanger the tourism and its development in the future.

\section{A. Conclusion \\ IV. CONCLUSION AND SUGGESTION}

Stakeholders will have opportunities to develop local culture-based tourism and their cooperation with other parties is very important. This will result in the productive synergy between the local government, the private sectors, and the local people; so that the development will also be exciting.

Stakeholders should not involve their sectoral ego and they should install a sense of togetherness particularly with the local people elements. In so doing, they are able to accomplish the purpose of improving life quality and of sustaining the relationships.

\section{B. Suggestion}

It is suggested that there should be a forum of tourism stakeholders in Banyumas. This forum will periodically discuss the matters of tourism and try to find solutions of the problems. 


\section{REFERENCES}

[1] Abdullah, Taufik. 2001. 'Integrasi Nasional, Globalisasi dan Kearifan

[2] Lokal', Antropologi Indonesia, Indonesian Journal of Social and Cultural Anthropology, Th. XXVI, No. 65 May-August. Jakarta: Universitas Indonesia's Anthropology Department - Yayasan Obor Indonesia.

[3] Cresswell, John. 2002. Desain Penelitian, Pendekatan Kualitatif dan Kuantitatif. Jakarta: KIK Press.

[4] Koderi, M. 1991. Banyumas Wisata dan Budaya. Edited by Ahmad Tohari. Purwokerto: CV Metro Jaya.

[5] Kohari, Khasan. 2009. Ragam Budaya Banyumasan untuk Aset Wisata. Kontribusi Vol. 2 Edisi 1, November 2009. Purwokerto: Unsoed's Research Institution.

[6] Miles and Huberman. 1992. Analisis Data Kualitatif. Jakarta: UI Press.

[7] Nasikun. 2005. Pemuliaan dan Pemberdayaan Kesenian Daerah di Bawah Tekanan Globalisasi. InterAksi Journal, Vol. 3, No. 1, May 2005. Purwokerto: Department of Sociology, Faculty of Social and Political Sciences, Universitas Jenderal Soedirman.

[8] Pitana and Gayatri. 2005. Sosiologi Pariwisata, Kajian Sosiologis terhadap Struktur, Sistem dan Dampak-dampak Pariwisata. Yogyakarta: Penerbit Andi.

[9] Rusidi. 1993. Pedoman Penelitian dan Penulisan Karya Ilmiah. Bandung: Service Unit - Penerbitan Institut Manajemen Koperasi Indonesia. 